\title{
Conflito no Saara Ocidental: um país além da miragem
}

\section{Adriano Alberto Smolarek ${ }^{1}$}

\section{RESUMO}

O presente trabalho analisa o conflito existente no Saara Ocidental. Sua origem, desenvolvimento, o panorama atual e algumas perspectivas.

Palavras-chave: Direito Internacional; Saara Ocidental; Marrocos

Embora conserve seu caráter latente por quase quatro décadas, o conflito do Saara Ocidental continua tão vivo quanto se veicula. E, conservar-se pleno de vigor, neste caso, alude à sua irresolutibilidade. Tanto no plano político, quanto na esfera jurídico-internacional, são visíveis as transgressões normativas que, a nada mais servem, senão a inflar, cada dia mais, tal conflito.

Resultado de um processo de descolonização mal conduzido pela Espanha, o Saara Ocidental, então conhecido como "Sáhara Español", é uma possessão que remonta à Convenção de Berlim de 1885, a qual dividiu o continente africano em colônias europeias. Desde 1960, a ONU, levando em conta o surgimento do anseio independentista da parte de diversos povos coloniais, emitiu a Resolução 1514 (XV), que trouxe mecanismos normativos de implementação para o processo de descolonização europeia da África. Todas as colônias se desfizeram até nossos dias, à exceção do Saara Ocidental.

Contrariando, tanto o parecer emitido por uma Comissão de Observadores da ONU, que confirmou o anseio de independência do povo do Saara Ocidental, quanto o Parecer Consultivo manifestado pela Corte Internacional de Justiça, ambos do ano de 1975, a Espanha - que atravessava um período instável de redimensionamento e

\footnotetext{
${ }^{1}$ Graduado em Direito pela Faculdade União, 2012. (Ponta Grossa - Paraná) 
redirecionamento político em virtude do frágil estado de saúde de Francisco Franco e as implicações do fim do franquismo - outorgou a administração do Saara Ocidental ao Marrocos e à Mauritânia. Tal episódio, conhecido como "O Acordo de Madrid", firmado secretamente em 14 de novembro de 1975, constitui-se, para Espanha, como "uno de los documentos más infamantes y con más perniciosos efectos de toda su historia" (MIGUEL, 2006). Não obstante a transgressão havida no plano jurídico, com o Acordo de Madrid, a Espanha ignora também a vontade política legítima de autodeterminação do povo saaraui.

Desde a outorga, o Marrocos, imbuído de um ideário nacionalista que prega a anexação de vários territórios da região do Magreb aos seus domínios - de tal forma a constituir o “Grande Magreb Árabe”, invade o Saara Ocidental. O episódio, batizado como a "Marcha Verde", configurou-se no envio de, aproximadamente, 350 mil pessoas de origem marroquina para tomar o território, bem como ocupar os edifícios abandonados pelos colonos espanhóis. Tal circunstância resultou no insurgimento da população saaraui que, organizada no prisma nacionalista através da Frente Polisário, funda a República Árabe Saaraui Democrática, em período concomitante à Marcha Verde. À titulo de informação, até o ano de 2013 mais de 80 países, de todos os continentes, já reconhecem o Saara Ocidental como país independente.

A repelência, tanto populacional, como militar, abrasa-se desde então. Grande parte da população civil saaraui que habitava as cidades abandona tudo, rumo ao interior do território. No que tange à Mauritânia, esta não detinha qualquer possibilidade de sustentar-se no front bélico devido à má-estruturação política do governo de então. Logo, em 1979, a Mauritânia assina um tratado de paz com o Saara Ocidental.

Considerando o momento político em que nasce o conflito - Guerra Fria, particularmente na década de 70 e doravante - temos a presença ideológica constante dos principais players daquele período: os americanos e toda a sua base-aliada na região, fornecendo armamentos e subsídios ao Marrocos; ao passo que a Argélia, Líbia, Vietnã e Cuba patrocinavam a causa saaraui. 0 conflito torna-se franco. São milhares as vítimas. 
O conflito só arrefece com a construção, pelo Marrocos, de um muro cuja extensão excede 1.200 quilômetros. Tal construção, batizada como o "Muro da Vergonha" divide o território do Saara Ocidental livre e o ocupado. A comunidade internacional age para intervir no conflito. Em 1981, a União Africana, órgão do qual o Saara Ocidental é membro pleno, cria um plano de paz, que só é chancelado pela ONU em 1986. Tal "plano" culmina, no ano de 1991, na instalação da MINURSO (Missão da ONU para o Referendo do Saara Ocidental). 0 primeiro logro desta missão consistiu no estabelecimento do cessar-fogo entre as partes. Tal missão tem por objetivo realizar um senso de pessoas que habitavam o Saara Ocidental na época da outorga e, assim, verificar, através de referendo, a vontade de autodeterminação daquele povo ou de anexação do mesmo ao Marrocos.

Todavia, o que se segue desde a implantação da missão, são inúmeras obstruções políticas arbitrárias por parte do Marrocos. Estas obstruções concernem, num primeiro momento, à discordância para com os requisitos de aptidão a voto no referendo. Muito embora, perante a comunidade internacional, o Marrocos demonstre boa índole para com a questão, no plano interno, o que se verifica, são inúmeras violações de Direitos Humanos como supressão cultural, discriminação racial, trabalhista e educacional, violação de mulheres e ativistas, prisões arbitrárias constantes e o uso constante e desmesurado de violência repressiva para com os saarauis. Ademais, o Marrocos utiliza-se dos recursos naturais do território ocupado. Dentre tais recursos encontra-se uma das maiores reservas de fosfato do mundo, bem como um imenso banco pesqueiro, praticamente inexplorado, do qual o Marrocos, além de retirar ganhos comerciais, ainda concede aos países da União Europeia o direito de exploração, mediante o pagamento de quantias em dinheiro.

Estando em atividade desde 1991, a MINURSO já detém o título de mais antiga missão da ONU em atividade. E o resultado ainda se está por galgar. Tamanha é a complexidade da contenda, que os dois últimos secretários-gerais da ONU - Kofi Annan e Ban Ki-Moon, nomearam enviados especiais para monitorar e dirigir os esforços. Entretanto, mesmo com estes especialistas, as partes não chegam a um consenso. No ano de 2012, por exemplo, ocorreram duas tentativas de reunião entre as partes. Lastimavelmente, em nenhuma das ocasiões foram verificados avanços, em virtude, 
principalmente, da intransigência marroquina em relação aos requisitos de habilitação para o voto no referendo e, ao foco particular da última reunião haver se voltado muito mais à exigência de diminuição do uso de violência por parte das autoridades marroquinas com os cidadãos saarauis.

A República Árabe Saaraui Democrática, muito embora detenha soberania reconhecida somente no além "Muro da Vergonha" (território do Saara Ocidental não invadido pelo Marrocos), possui a totalidade de seu território reconhecido internacionalmente, além da vinculação inconteste de seu povo àquele território. Estes elementos aliados às condições indignas em que vive a população saaraui denotam a premência da efetivação do processo de descolonização, fazendo jus ao direito inalienável de autodeterminação que lhes é, por natureza, devido.

\section{Referências Bibliográficas}

ASSOCIATION DE SOUTIEN À UN RÉFÉRENDUM LIBRE ET RÉGULIER AU SAHARA OCCIDENTAL (ARSO). Disponível em <http://www.arso.org>. Acessado em Janeiro de 2013.

INTERNATIONAL COURT OF JUSTICE. Western Sahara. Advisory Opinion. Disponível em <http://www.icj-cij.org/docket/files/61/6195.pdf >. Acessado em Janeiro de 2013.

MIGUEL, Carlos Ruiz. El Sahara Occidental y Espanha: Historia, Política y Derecho. Analisis Crítico de La Política Exterior Española. 1a ed. Madrid: Dykinson. 1995. Los Acuerdos de Madrid, inmorales, ilegales y politicamente suicidas. La Ilustración Liberal. №26. 2006. Disponível em <http://www.ilustracionliberal.com/26/los-acuerdos-de-madrid-inmoralesilegales-y-politicamente-suicidas-carlos-ruiz-miguel.html\#_ftnref3>. Acessado em Janeiro de 2013. 
ORGANIZAÇÃO DAS NAÇÕES UNIDAS (ONU). Resolução da Assembléia Geral 1514 (XV) de $1960 . \quad$ Disponível em $\quad$ http://daccessods.un.org/TMP/7846177.81639099.html>. Acessado em Janeiro de 2013. SANTAYANA, Mauro. Dossiê da Guerra do Saara. Rio de Janeiro: Paz e Terra. 1987. SUZIN, Giovana; DAUDÉN, Laura. Nem Paz Nem Guerra: Três Décadas de Conflito no Saara Ocidental. 1aㅡ. ed. Rio de Janeiro: Tinta Negra Bazar Editorial. 2011. 